Lidija Barjaktarovic ${ }^{1}$

Biljana Lazarevic ${ }^{2}$ Veljko Davidovic ${ }^{3}$
JEL: A20, G30, G53

DOI: 10.5937/industrija47-23211

UDC:004:658.5(497.11)

005.92:004.63

Original Scientific Paper

\title{
Is Serbian Economy Ready to Use Digital Tools in Business Decision-Making Process? ${ }^{4}$
}

\author{
Article history: \\ Received: 17 August 2019 \\ Sent for revision: 5 September 2019 \\ Received in revised form: 28 September 2019 \\ Accepted: 28 September 2019 \\ Available online: 15 October 2019
}

\begin{abstract}
The aim of this article is to emphasize the importance of reactive to proactive approach in further simulation development and appliance, in order to increase the level of financial literacy. The subject of this paper is to get the opinion of Serbian employees, managers and owners of companies on the use of digital simulation Coin \& Fund in companies' business. The conducted research in 2019, on the basis of the questionnaire completed by 207 respondents out of 1,410 respondents $(14.68 \%$ respondent rate) who received the questionnaire, confirmed that Serbian economy is ready to use digital tools in the lifelong learning process and business decision-making process. Respondents evaluated that Coin \& Fund is extremely useful and supportive tool which helps in acquiring financial knowledge. Furthermore, it is extremely useful for understanding connection between made decisions and achieved financial result. Finally, the simulation represents company's real business in an adequate way. It is important to stress the observations connected to the credible and reputable Coin \& Fund team, and good cooperation between economy and academia.
\end{abstract}

Keywords: Coin \& Fund, digital tools, simulation, business decision-making process, lifelong learning

\footnotetext{
${ }^{1}$ Singidunum University Belgrade, lbarjaktarovic@singidunum.ac.rs

${ }^{2}$ Casa Forte Ltd Belgrade

${ }^{3}$ Casa Forte Ltd Belgrade

${ }^{4}$ This research paper was a part of the project no. 47028, in the period 2011-2019, financed by the Serbian Ministry of Science and Technological Development
} 
Barjaktarović L. et al.: Is Serbian Economy Ready to Use Digital Tools in Business...

\title{
Da li je sprska privreda spremna da koristi digitalne alate u procesu poslovnog odlučivanja?
}

\begin{abstract}
Apstrakt: Cilj ovog članka je da se istakne važnost od reaktivnog ka proaktivnom pristupu u daljem razvoju i primeni simulacije, u svrhu povećanja nivoa finansijske pismenosti. Predmet ovog rada je da se dobije mišljenje zaposlenih, menadžera i vlasnika kompanija u Republici Srbiji o upotrebi Coin \& Fund digitalne simulacije u poslovanju kompanija. Sprovedeno istraživanje u 2019. godini, na osnovu 207 popunjenih upitnika od 1.410 ispitanika $(14,68 \%)$ kojima su isti prosleđeni, je potvrdilo da je srpska privreda spremna da koristi digitalne alate u procesu celoživotnog učenja $i$ poslovnog odlučivanja. Ispitanici su ocenili da je Coin \& Fund izuzetno koristan $i$ upotrebljiv alat koji pomaže u sticanju finansijskog znanja. Dalje, izuzetno je koristan za razumevanje povezanosti donetih poslovnih odluka i ostvarenog finansijskog rezultata kompanije. I na kraju, simulacija predstavlja realno poslovanje preduzeća na adekvatan način. Važno je naglasiti da su u ostalim zapažanjima, ispitanici istakli kao pozitivno kredibilan i ugledan Coin \& Fund tim, i dobar primer saradnje privrede i akademske zajednice.
\end{abstract}

Ključne reči: Coin \& Fund, digitalni alati, simulacija, process poslovnog odlučivanja, celoživotno učenje

\section{Introduction}

Coin \& Fund is an on-line educational business simulation developed in the Republic of Serbia as a result of partnership Casa Forte Ltd Belgrade and Singidunum University Belgrade. Coin \& Fund is a virtual company with trade as basic activity. The idea for creation of the simulation comes from Casa Forte Belgrade. It was the result of long experience in strategic business improvement, with a special focus on sales-controlling consultative work of Casa Forte's representatives. They noticed that decision makers in small and medium sized companies are usually not aware of the impact their decisions have on overall company's business through basic financial reports, i.e. chosen ratio numbers; especially in terms of providing liquidity and profitability at the same time, i.e. understand managerial profit \& loss account; the simulation is based on Return on Investment defined on the basis of DuPont formula (Barjaktarovic et al., 2018; Knezevic et al., 2017). Furthermore, employees are not interested in activities of other departments of the company and they do not have thebig picture. Moreover, many companies have space to improve business processes. Finally, lot of employees including owners of the business do not have basic money management skills (such as depositing, crediting, converting or investing money). According to 
Barjaktarović L. et al. : Is Serbian Economy Ready to Use Digital Tools in Business...

Erste bank's research (2019) important topics for education are: depositing, money management (family finances) and investing.

The basic aim of development and usage of Coin \& Fund is to increase the overall level of financial literacy. Partners in development of the simulation organized different events in the previous period in order to promote the simulation and stress the importance of getting and applying financial knowledge in daily life. Furthermore, on those events Coin \& Fund team has received valuable inputs for the further development of the simulation (verbally or in written form). So, the aim of this paper is to emphasize the importance of reactive to proactive approach in further development and appliance of the simulation, in order to increase the level of financial literacy. Accordingly, the subject of this paper is to get the opinion of Serbian employees, managers and owners of companies on digital simulation Coin \& Fund uses in companies' business.

Modules of the simulation are: financial reports, stock exchange, exchange office, bank and trade. The simulation is driven by financial ratio numbers. Coin \& Fund is in Serbian language. Barjaktarovic et al. (2019) presented other simulations on the market, specifics of Coin \& Fund comparing to other competitors, general characteristics and course of the simulator, and hard and soft skills which students get by applying it.

The crucial challenges which Coin \& Fund team has had: forming of competent and credible team, communication between economists and IT (information technology) experts in the team, creation of a stable and sustainable architecture system complex, development of immediate booking of business transactions after decisions are made (running of profit and loss account), fulfilling strict standards prescribed for companies and academia, and permanent improvement of the simulation on the basis of suggestions of participants who used it. Relevant factors for creation of the educative business simulation Coin \& Fund are (Plecic, 2017): functionality, complexity, and easy way of usage, time of usage, customer experience, and overall applicability. Also, Coin \& Fund team respected Code of Ethics and Professional Conduct (ACM, 1992). Furthermore, Coin \& Fund team is committed to the values of UNICEF Innovation Fund, which are connected to the increase of financial literacy of young people by using modern and innovative technology (UNICEF, 2019).

The crucial peculiarities of Coin \& Fund for human capital of Serbian companies are: 1 ) it is based on rules which are applicable in real business and corporative principles of work, 2) interdisciplinary approach in construction/creation of the simulation, 3) simplicity and understandability; 4) immediate booking of transactions after decisions are made, 5) existence of managerial profit and loss account. Managerial profit and loss account is an 
Barjaktarović L. et al.: Is Serbian Economy Ready to Use Digital Tools in Business...

internal report relevant for daily business of the company and fulfilment of defined targets.

It is important to say that Coin \& Fund is the first mover in the Republic of Serbia, on the basis of analysed characteristics of offered simulations on our market (Barjaktarovic et al., 2019). Due to the published researches for Serbia, there is space for further development of knowledge-based economy and information society, innovation and competitiveness (Nedic et al., 2014; Cvetanovic et al., 2015). So this is a relevant topic for the research which will be used by different stakeholders in academia and economy.

Accordingly, basic hypothesis of the research is that Serbian economy is ready to use digital tools developed through cooperation between companies and academia. It leads to introducing innovative tools in lifelong learning processes.

The paper is organized in five chapters with introduction and conclusion. The second chapter represents literature review. In the third chapter methodology is described. Research results are presented in the fourth chapter.

\section{Literature review}

Simulation is "the process of designing model of real system and execution of experiments together with it in order to understand system's behaviour or evolution of different strategies (within determined boundaries or within defined criteria)" (Shannon, 1995). Moreover, it can be defined that business simulation represents activities which describe real states from the outside worlds (Prensky, 2001), but in protected and controlled environment, in order to become familiar with particular business process and final results (Dusak, 1992; Milovanovic et al, 2016). Furthermore, well established simulations are a powerful tool (Finkelsten et al., 2005) for different users for preparing quantitative analysis (Shannon, 1975; Milovanovic et al., 2013; Kaurin et al., 2011), but also one of the most efficient way of learning highly sophisticated skills, such as: analysis, synthesis and creating new knowledge (Leger et al., 2011). They cover all processes and possible decisions influenced by external factors within the company's business decision making process which is complex, and for creating and establishing it required huge number of experts with different competences. Simulations try to solve problem, motivate and promote active learning (Plecic, 2017).

Different researches showed that appliance of simulations improves learning outcomes connecting abstract concepts with concrete experience and providing participants (students and employees) with better understanding by applying active learning and problem solving (Hunzeker and Harkness, 2014). 
Barjaktarović L. et al.: Is Serbian Economy Ready to Use Digital Tools in Business...

Usage of simulations represents a very good thoughtful model for acquiring business skills (Schrage, 2000; Hunzeker and Harkness, 2014). Appliance of simulation in companies encourages sustainable learning (Fink et al., 2014), i.e. lifelong and constructive learning (Schwänke, 2009). Employers always prefer employees who achieve better results and have more competences. According to LePrince's research (2013), getting bigger picture is the skill which results from permanent learning and development of employees.

According to the research executed on Slovakian Presov's University, business simulations can be used as an efficient tool for development of company's human and total intellectual capital (Birknerova, 2010). Furthermore, in the case of employees, it is important that the simulation has a specific purpose, and is not general (Your Training, 2019).

Topic of this paper is relevant due to the facts that different published researches confirmed that in the Western Balkan countries (including the Republic of Serbia) has a lag in readiness for development of knowledgebased economy, innovation and competitiveness compared to the European Union (Cvetanovic et al, 2015). Furthermore, there is lag in the development of the information society as a whole in those countries (Nedic et al., 2014).

\section{Research Methodology}

For the sake of this research, the authors have devised a questionnaire/survey of 12 questions which are subsumed under the following five categories: I - Personal data (3 questions), II - Companies data (2 questions), III - Coin \& Fund (7 questions). In the third part of the questionnaire, five questions have used the same ordinal fine-point scale ( 1 to 5 for different simulation features, where 5 is the highest positive score, and the level 1 is the lowest score feature) and two questions have used the open form in terms of other observations and proposals for further development. The questionnaire was prepared in accordance with relevant factors for the creation of simulation, mentioned in Introduction. The questionnaire draft had initially been distributed to quantitative experts for the revision before it was distributed to the subjects of this research. The questionnaires were emailed to participants on all of mentioned promoted events of Coin \& Fund and announced on social media profiles (Linkedln and Instagram) of Casa Forte Belgrade.

The questionnaire was completed by 207 respondents out of 1,410 respondents who had received the questionnaire in the period of mid-May to 
Barjaktarović L. et al.: Is Serbian Economy Ready to Use Digital Tools in Business...

mid-August 2019, so the response rate amounted to 14.68 per cent, which could be defined as "reasonable" (Sivo et al., 2006). Furthermore, it could be defined as acceptable due to the announced results in the researches of Kilic et al. (2011), Graca et al. (2015), Homburg et al. (2015) and Petkovic et al. (2019) where response rates were $11 \%, 13.22 \%, 18 \%$, and $13.77 \%$, respectively.

The formed sample includes the following: 1) industry structure: $61.8 \%$ services, $36.2 \%$ production and $2 \%$ trade, 2) size of the company in terms of number of employees: $46.9 \%$ small companies (up to 50 employees), $34.3 \%$ large companies (above 250 employees), and 18.8\% medium sized companies (between 50 and 250 employees), 3) educational structure: 60.9\% economics (where $58.9 \%$ has bachelor degree and $2 \%$ has high school) and $39.1 \%$ non-economics (where $20.3 \%$ has high non-economic bachelor degree and $18.8 \%$ has high school). 151 respondents (72.95\% of the sample) answered to other observations and 121 respondents (58.45\% of the sample) proposed suggestions for further development.

The data analysis employed the use of descriptive statistics.

\section{Results and Discussion}

Since the survey contains three question groups, the next part presents the results of third question groups including other observations and proposed suggestions for further development.

Table 1. Coin \& Fund Questionnaire's summary

\begin{tabular}{|l|l|l|l|l|l|l|l|}
\hline Industry & \multicolumn{2}{|c|}{ Respondents } & \multicolumn{3}{|c|}{ Average rate per analysed criteria in the question } \\
\cline { 2 - 8 } & No & $\%$ & $\begin{array}{l}\text { Usefuln } \\
\text { ess of } \\
\text { the tool }\end{array}$ & $\begin{array}{l}\text { Assistance in } \\
\text { accepting } \\
\text { financial } \\
\text { knowledge }\end{array}$ & $\begin{array}{l}\text { Understandin } \\
\text { g connection } \\
\text { between } \\
\text { decision } \\
\text { made } \\
\text { income } \\
\text { statement }\end{array}$ & $\begin{array}{l}\text { The } \\
\text { simplicity } \\
\text { of } \\
\text { navigation } \\
\text { through } \\
\text { the } \\
\text { simulation } \\
\text { simulation } \\
\text { shows } \\
\text { real } \\
\text { business }\end{array}$ \\
\hline Services & 127 & 61.35 & 4.84 & 4.75 & 4.73 & 4.25 & 4.7 \\
\hline Production & 75 & 36.23 & 4.44 & 4.49 & 4.48 & 4.31 & 4.47 \\
\hline Trade & 4 & 1.93 & 4.50 & 4.50 & 4.50 & 4.25 & 3.75 \\
\hline Other & 1 & 0.48 & 5.00 & 5.00 & 5.00 & 5.00 & 5.00 \\
\hline Total & 207 & 100 & 4.69 & 4.65 & 4.64 & 4.28 & 4.6 \\
\hline
\end{tabular}

Source: Authors' calculation 
Barjaktarović L. et al. : Is Serbian Economy Ready to Use Digital Tools in Business...

On the first question connected to the evaluation of the usefulness of the tool, respondents answered as follows: $70.5 \%$ ranked it with 5, as extremely useful, $27.1 \%$ ranked it with 4 , as useful, $1.9 \%$ ranked it with 3 , neither useful nor useless and $0.5 \%$ ranked it with 1 , as extremely useless. It can be noticed that the smallest number of respondents comes from trade industry, but the majority of respondents evaluated the tool as extremely useful.

Figure 1. Evaluation of the usefulness of Coin \& Fund

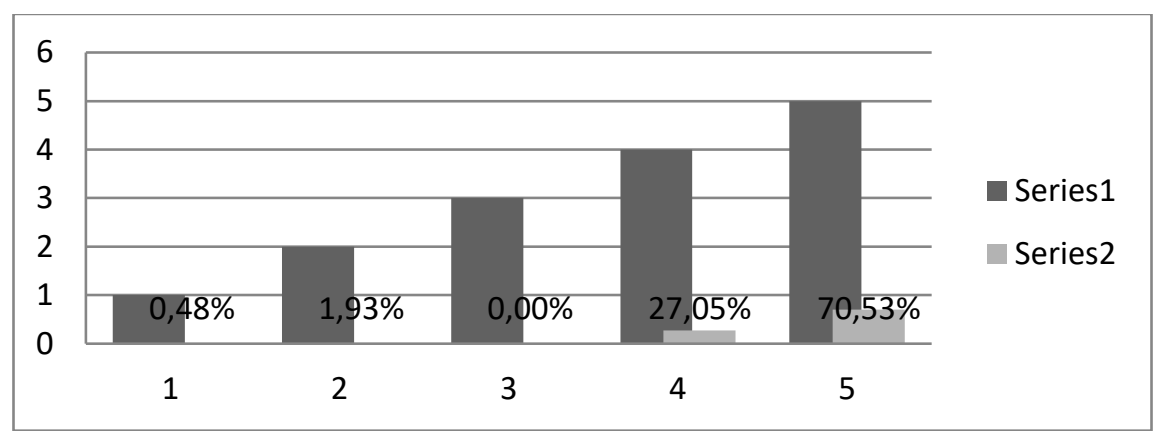

Source: Authors' presentation on the basis of completed questionnaires

On the second question connected to the evaluation of the tool as an assistance in accepting financial knowledge, respondents answered as follows: $70.5 \%$ ranked it with $5,25.6 \%$ ranked it with $4,2.90 \%$ ranked it with 3 , $0.48 \%$ ranked it with 2 , and $0.48 \%$ ranked it with 1 . It can be noticed (given in other observations) that majority respondents was not familiar with the functioning of the Belgrade Stock Exchange, appliance of buying and selling rate in exchange transactions and costs connected to getting the loan or depositing funds.

Figure 2. Evaluation of Coin \& Fund as an assistance in accepting financial knowledge

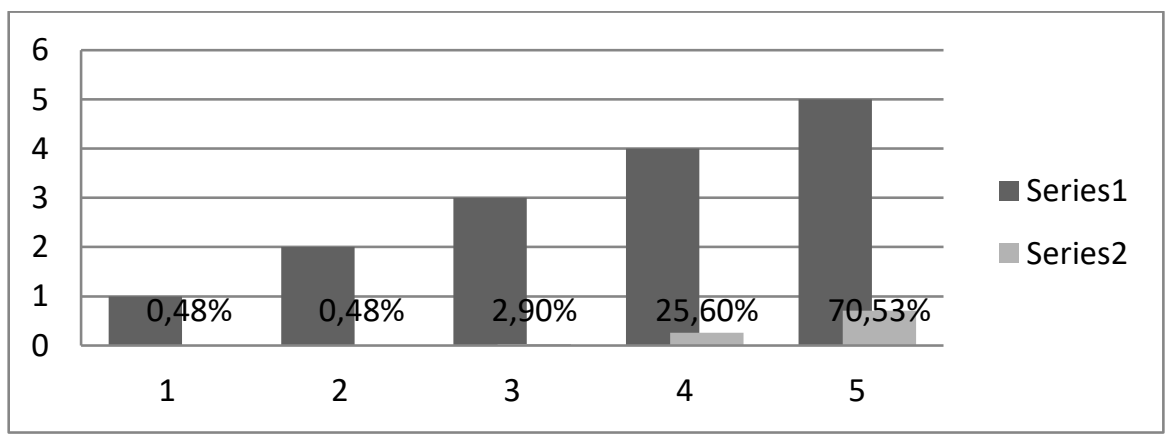

Source: Authors' presentation on the basis of completed questionnaires 
Barjaktarović L. et al. : Is Serbian Economy Ready to Use Digital Tools in Business...

On the third question connected to the evaluation of the tool in understanding connection between decisions made and income statement (company's success), respondents answered as follows: $68.12 \%$ ranked it with 5, as extremely supportive, $28.50 \%$ ranked it with 4 , as supportive, $2.90 \%$ ranked it with 3 , neither supportive nor not supportive, and $0.48 \%$ ranked it with 1 , as not supportive at all. It can be noticed that different users of the simulation had focus on various things (given other observations), but the experts (CFOs - Chief Financial Officers) put accent on the following decisions and impact on financial reports: employment, buying or leasing of the property, ratio numbers, and cash flow and at the end on buying and selling of goods.

Figure 3. Evaluation of Coin \& Fund in understanding connection between decisions made and income statement (company's success)

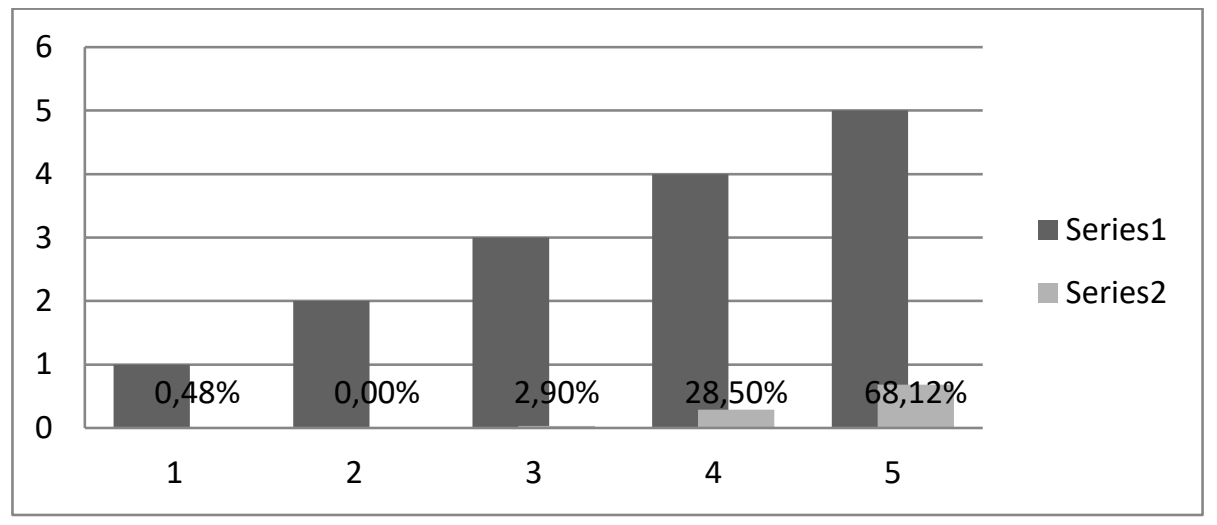

Source: Authors' presentation on the basis of completed questionnaires

On the fourth question connected to the simplicity of navigation through the simulation, respondents answered as follows: $38.16 \%$ ranked simplicity with $5,52.66 \%$ ranked it with $4,8.21 \%$ ranked it with $3,0.48 \%$ ranked it with 2 and $0.48 \%$ ranked it with 1 .

On the fifth question connected to extent to which the simulation shows the real business, respondents answered as follows: $69.08 \%$ evaluated as extremely realistic with rank $5,24.15 \%$ evaluated as realistic with rank 4 , $4.83 \%$ evaluated neither real nor unreal, with rank $3,1.45 \%$ evaluated unreal, rank 2 and $0.48 \%$ evaluated as extremely unreal, rank 1 .

On the basis of received answers, it can be concluded that Coin \& Fund is extremely useful and supportive tool which helps acquiring financial knowledge. Furthermore, it is extremely useful for understanding connection between made decisions and achieved financial result. Finally, the simulation 
Barjaktarović L. et al.: Is Serbian Economy Ready to Use Digital Tools in Business...

represents real business in an adequate way. However, the simplicity of navigation through the simulation can be easier.

Figure 4. Evaluation of the simplicity of navigation through Coin \& Fund

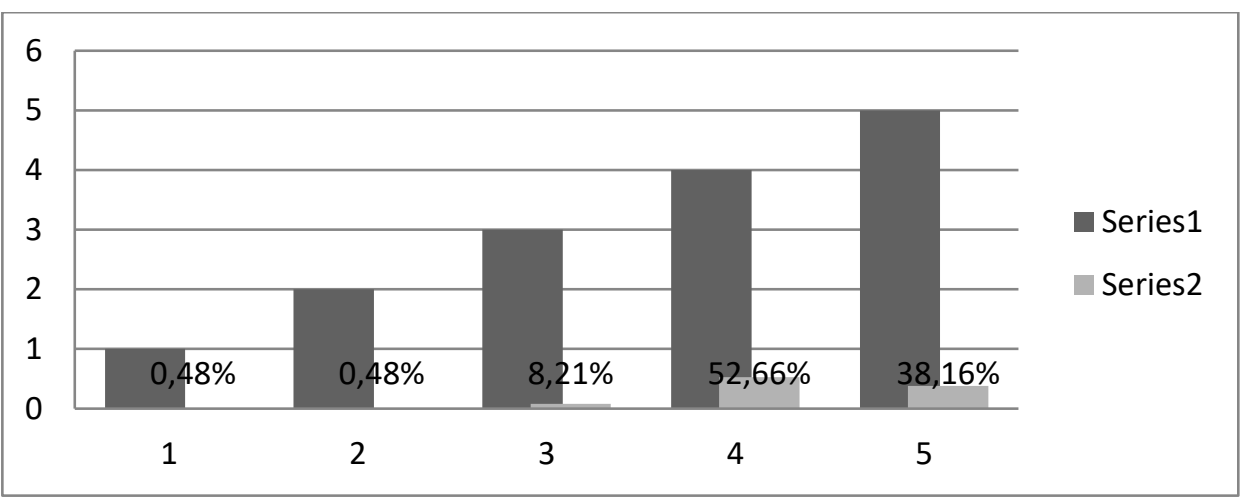

Source: Authors' presentation on the basis of completed questionnaires

Figure 5. Evaluation to extent to which Coin \&Fund shows the real business

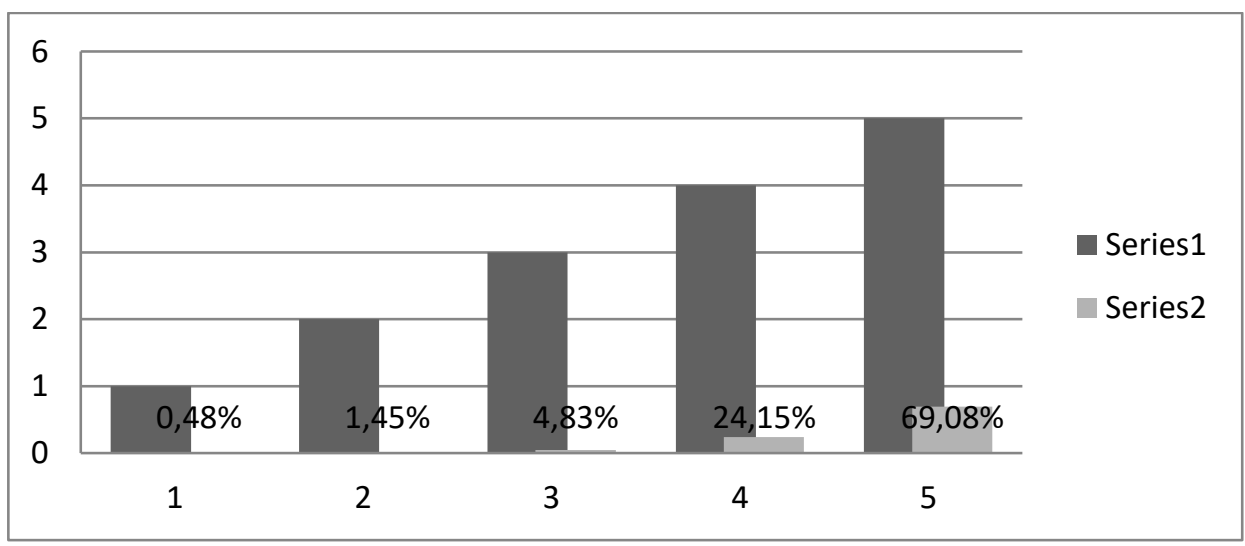

Source: Authors' presentation on the basis of completed questionnaires

Other observations can be summarized as follows: 1) it is good that the simulation is result of partnership cooperation between representatives of company and university, i.e. economy and academia; 2) the key personnel have credentials and experience required in economics, finance, and banking industry to deliver the presented tool. The team will require more technical resources for further development and maintenance of the simulation. 3) It is an educational tool focused on finance element in made decisions. It is a clear market need. 4) It is useful for employees of companies and their business 
Barjaktarović L. et al. : Is Serbian Economy Ready to Use Digital Tools in Business...

partners. 4) It is a modern and active tool for assistance in the business. It is in the function of lifelong learning process of all stakeholders within the company. It can be considered as an innovative tool on the Serbian market. 5) It can be useful for entrepreneurs and persons who plan to start-up own business. It is supporting for transformation process within the company. 6) It is established in accordance with business rules applicable in the practice. 7) It will be good to introduce more indicators connected to the creditworthiness of the company and limits for maximal credit in use. 8) Good way of promoting the simulation. 9) Supports career development and it more strongly links finance to entrepreneur's spirit.

Proposals for further development can be summarized as follows: 1) to prescribe more decisions, 2) to introduce trade on international market; furthermore to extend companies' activities in the field of sales - to be wholesalers and retailers at the same time, 3) include other factors which exist on the market; 4) introduce production module, as well as IT, tourism and hospitality, real-estate companies etc. 5) extend usage of the simulation globally.

On the basis of received answers in questionnaires, it can be concluded that main hypothesis of the research is confirmed i.e. Serbian economy is ready to use digital tools developed in cooperation between companies and academia. It leads to introducing innovative tools in lifelong learning process.

\section{Conclusion}

Serbian economy is ready to use digital tools in lifelong learning process and business decision-making process. Respondents evaluated that Coin \& Fund is an extremely useful and supportive tool which helps acquiring financial knowledge. Furthermore, it is extremely useful for understanding connection between made decisions and achieved financial result. Finally, the simulation represents real business in an adequate way. It is important to stress observations connected to the credible and reputable Coin \& Fund team, and good cooperation between economy and academia.

Coin \& Fund team has an ambition to further develop production and Business to Business (B2B) trade module. Currently it developed B2B, a trade company, and with development of production module and Customer, it will cover Business to Customers (B2C). Moreover, there is a clear market need and a competitive position of the simulation. So it has potential for market growth in appliance (and commercialization) of Coin \& Fund in lifelong learning process in Serbia and the region. However, further development of 
Barjaktarović L. et al. : Is Serbian Economy Ready to Use Digital Tools in Business...

the simulation will lead to less simplicity i.e. more complexity in navigation thought Coin \& Fund.

Coin \& Fund is already in use in the teaching process at the Singidunum University. Singidunum University is the first university in Serbia that uses digital simulation approach in Serbia, in order to prepare students for future employment.

Further researches will be connected to improvement of the existing modules and introducing new ones. Special focus will be on introducing tests on knowledge before the usage of the simulation, and on the acquired knowledge after using Coin \& Fund.

\section{References}

ACM. (1992). Code of Ethics and Professional Conduct. Retrieved from: http://www.acm.org/constitution/code.htm

Barjaktarovic, L., Lazarevic, B., \& Davidovic, V. (2019, April). The importance of appliance Coin \& Fund in teaching. Paper presented at Synthesis 2019 International Scientific Conference on Information Technology and Data Related Research, Novi Sad. Retrieved from: http://portal.sinteza.singidunum.ac.rs/paper/645

Barjaktarovic, L., Jovic, Z., \& Milojevic, M. (2018). Poslovne finansije. Beograd, Republika Srbija: Univerzitet Singidunum.

Birknerova Z. (2010). The use of simulation business games in university education. Journal of Science andEducation Policy (BJSEP), 4 (2), 202-2015. Retrieved from: http://bjsep.org/getfile.php?id=77

Cvetanovic, S., Ilic, V., Despotovic, D., \& Nedic., V. (2015). Spremnost za razvoj ekonomije baziranje na znanju, inovativnosti i konkurentnosti zemalja Zapadnog Balkana Industrija, 43(3), 27-53. doi:10.5937/industrija43-7908

Dusak, V. (1992). Simulacijsko modeliranje u procesu odlucivanja. Paper presented at the the conference organized by the Faculty of organisation and informatics, Varazdin. Retrieved from: https://hrcak.srce.hr/79719

Erste bank a.d. Novi Sad. (2019). Erste bank established platform Erste znali, overall program about finance literacy. Retrieved from https://www.erstebank.rs/sr/onama/press/saopstenja/2019/03/14/erste-banka-pokrenula-ersteznalisveobuhvatni-program-finansijske-edukacije

Fink S, Kiili K., \&Bullinger A.C. (2014). Measuring Game Experience and Learning Effects of Business Games. Paper presented at conference of the International Simulation and Gaming Association, Dornbirn. Retrieved from: https://tutcris.tut.fi/portal/en/publications/measuring-game-experience-andlearning-effects-of-business-games

(7cd7717a-21d4-411d-a5811bf01bf65547).html

Finkelstein, N. D., Adams, W. K., Keller, C. J., Kohl P. B., Perkisn K. K., Podolefsky N., Reid, S., \& LeMaster, R. (2005). When learning about the real world is better done 
Barjaktarović L. et al.: Is Serbian Economy Ready to Use Digital Tools in Business...

virtually: a study of substituting computersimulations for laboratory equipment Physical Review, Special Topics: Physics Education Research - Resarch 1, 010103.doi: 10.1103/PhysRevSTPER.1.010103

Graca, S., Barry, J., \&Doney, M. (2015). Performance outcomes of behavioral attributes in buyer-supplier relationships Journal of Business \& Industrial Marketing, 30(7), 805-816. doi:10.1108/JBIM-04-2014-0072

Homburg, C., Vomberg, A., Enke, M., \& Philipp H. Grimm (2015). The loss of the marketing department's influence: is it really happening? And why worry? Journal of the Academy of Marketing Science 43, 1-13. doi: 10.1007/s11747-014-0416-3

Hunzeker, M., \& Harkness K. (2014). The Strategy Project: Teaching Strategic Thinking through Crisis Simulation PS: Political Science \& Politics, 47, 513-517. doi:10.1017/S104909651400047X

Graca, S., Barry, J., \& Doney, M. (2015). Performance outcomes of behavioral attributes in buyer-supplier relationships. Journal of Business \& Industrial Marketing, 30(7), 805-816. doi:10.1108/JBIM-04-2014-0072

Kaurin, T., Bulatovic, N., \& Anucojic, D. (2011). Modeliranje $i$ simulacije kao sistemi podrske u odlucivanju. Paper presented at INFO TECH 2011 - ICT Conference \& Exhibition, Vrnjacka Banja. Retrieved https://scholar.google.com/citations?user=UxuB-SMAAAAJ\&hl=en

Kilic, K., Ulusoy, G., Gunday, G., \& Alpkan, U. (2014). Innovativeness, operations priorities and corporate performance: An analysis based on taxonomy of innovativeness Journal of Engineering and Technology Management, 35, 115133. doi: 10.1016/j.jengtecman.2014.09.001

Knezevic, G, Stanisic, N., \& Mizdrakovic, V. (2017). Analiza finansijskih izveštaja namenjena tržištu Republike Srbije. Beograd, Republika Srbija: Univerzitet Singidunum.

LaPrince, S. (2013). A qualitative exploration of management education: business school offerings in comparison to employer expectations (PhD thesis). Capella University, Mineapolis, United States of America. Retrieved from: http://pqdtopen.proquest.com/doc/1425346438.html?FMT=AI

Leger, P.M., Charland, P, Feldstein, H.D., Robert, J., Babin, G., \& Lyle, D. (2011). Business simulation training ininformation technology education. Journal of Information Technology Education, 10 (1), 39-53. Retrieved from: https://www.learntechlib.org/p/111511/

Milovanovic, Z., Stojanovic, M., \& Regodic, D. (2016). Simulacija poslovnog procesa u turizmu primenom SIMPROCESS softvera. Paper presented at Sinergija University Scientific Conference, Biljeljina. Retrieved from: http://doisrpska.nub.rs/index.php/SNG/article/view/3056

Milovanovic, S., Pantelic, I., \& Damnjanovic, I. (2013). Povećanje kvaliteta kroz integrisanu upotrebu simulatora. Paper presented at conference ETRAN, Zlatibor. Retrieved from: https://www.researchgate.net/publication/280947338 Povecanje_kvaliteta_edukativnog_procesa_kroz_integrisanu_upotrebu_simulator a

Nedic, V., Cvetanovic, S., \& Despotovic, D. (2014). IKT kao komponenta razvoja ekonomije znanja zemalja Zapadnog Balkana Industrija, 42(4), 55-77. doi:10.5937/industrija42-6313

Petkovic, G., Konjikusic, S., Barjaktarovic, L., \& Pindzo, R. (2019). What is the real state of financial management in companies in the Republic of Serbia? 
Barjaktarović L. et al.: Is Serbian Economy Ready to Use Digital Tools in Business...

Management: Journal of Sustainable Business and Management Solutions in Emerging Economies, 24(2), 23-34.doi:10.7595/management.fon.2018.0002

Plecic K. (2017). Razvoj novog modela primene poslovnih simulacija u visokoškolskom obrazovanju. (PhD thesis). Singidunum University, Belgrade, Republic of Serbia.

Prensky, M. (2001). Digital game-based learning. New York, United States of America: McGraw Hill.

Schrage M. (2000). Serious play: How the world's best companies simulate to innovate. Boston, United States of America: Harvard Business School Press.

Shannon, R. (1975). Systems simulation - The Art and Science. New York, United States of America: Englewood Cliffs, Prentice-Hall.

Schwänke U. (2009). Sustainable Learning - how Storyline can support it. Paper presented at Nordic Storyline Conference, Gothenburg.Retrieved from: https://www.semanticscholar.org/paper/Suistainable-Learning-how-Sotryline-canSupport-it/2e9a15a679d8cf75260faecc6083ccc662e17aa9

Sivo, S.A., Saunders, C., Chang, Q.,\& Jiang, J.J., (2006). How Low Should You Go? Low Response Rates and the Validity of Inference in IS Questionnaire Research. Journal of the Association for Information Systems, 7(6), 351-414.

Your Training. (2019). Using Simulations in Training - White Paper. Retrieved from: http://www.yourtrainingedge.com/wp-content/uploads/2010/01/Using-Simulationsin-Training-White-Paper-February-2011.pdf

UNICEF. (2019). What we do. Retrieved from https://www.unicef.org/serbia/inovacionifond-konkurs-tehnologije 